\title{
Increased S100A4 expression combined with decreased E-cadherin expression predicts a poor outcome of patients with pancreatic cancer
}

\author{
YASUHISA OIDA ${ }^{1,2}$, HITOSHI YAMAZAKI ${ }^{2}$, KOSUKE TOBITA $^{1}$, MASAYA MUKAI $^{1}$, YASUO OHTANI ${ }^{1}$, \\ NORIYUKI MIYAZAKI ${ }^{2}$, YOSHIYUKI ABE ${ }^{2}$, TOSHIHIDE IMAIZUMI ${ }^{1}$, HIROYASU MAKUUCHI ${ }^{1}$, \\ YOSHITO UEYAMA $^{2}$ and MASATO NAKAMURA ${ }^{2}$
}

Departments of ${ }^{1}$ Surgery and ${ }^{2}$ Pathology, Tokai University School of Medicine, Bohseidai, Isehara, Kanagawa 259-1193, Japan

Received April 10,2006; Accepted May 9, 2006

\begin{abstract}
The calcium-binding protein, S100A4, with an inverse association of E-cadherin, is known to correlate with prognosis in various cancers. In this study, we investigated the expression of the S100A4 and E-cadherin status in relation to the clinicopathological parameters of pancreatic cancer. The expression status of these two proteins was examined in 72 specimens of primary pancreatic carcinoma with immunohistochemistry. Fifty-six of 72 (78\%) surgical specimens of primary pancreatic cancer were positive for S100A4 according to immunohistochemistry. Thirty-one $(43 \%)$ specimens of pancreatic cancer showed positive expression of E-cadherin. The inverse association of S100A4 and E-cadherin expression was significant in the cancers $(\mathrm{p}<0.0001)$. The S100A4 expression correlated significantly with the pathological $\mathrm{T}$ stage and poorer prognosis $(p=0.024)$. The 41 E-cadherin-negative cases showed poorer prognoses and a higher incidence of liver metastasis ( $\mathrm{p}=0.0344, \mathrm{p}=0.027)$. The 10 cases with $\mathrm{S} 100 \mathrm{~A} 4$-negative/Ecadherin-positive cancers showed a significantly better prognosis than the others $(\mathrm{p}<0.05)$. The histological grade $(\mathrm{p}=0.004)$, nodal status $(\mathrm{p}<0.0001)$ and S100A4-positive status $(\mathrm{p}=0.048)$ were highly significant independent prognostic predictors $(\mathrm{p}<0.05)$. These results suggest that S100A4 overexpression combined with reduced E-cadherin expression play important roles in tumor progression and metastasis in pancreatic cancer. The combined examination of these two molecules is useful in evaluating the outcome of pancreatic cancer patient.
\end{abstract}

Correspondence to: Dr Masato Nakamura, Department of Pathology, Tokai University School of Medicine, Bohseidai, Isehara, Kanagawa 259-1193, Japan

E-mail: mnakamur@is.icc.u-tokai.ac.jp

Key words: S100A4, E-cadherin, pancreatic cancer, prognosis, metastasis

\section{Introduction}

Pancreatic cancer is the fourth leading cause of cancerrelated death in men and women in developed countries and the incidence seems to be increasing (1). Despite advances in diagnosis and staging, the overall 5-year survival rate for patients diagnosed with this cancer averages less than $1 \%$. Only $10 \%$ of pancreatic cancer patients have localized disease amenable to surgical resection at the time of diagnosis. This has been explained by the difficulty of early detection of the neoplastic process, lack of effective treatment, and limited knowledge of the peculiarities in the biological features of pancreatic cancer (2).

The S100 family of calcium-binding proteins are involved in a variety of physiological functions, such as cellular proliferation, adhesion and motility (3). S100A4, a small member of the S100 family, was formerly known as p9Ka or mts 1 and has been characterized as a 'metastasis-related gene'(4). Originally the mouse homologue was identified as a gene whose expression was elevated in metastatic mammary epithelial cell lines (5). The elevated level of S100A4 protein correlated with the metastatic potential of mammary epithelial cells in two independent rodent models of breast neoplasms (6-8). The induced overexpression of S100A4 increased the metastatic potential in several rodent models of mammary carcinogenesis $(9,10)$. A high incidence of pulmonary metastases of mammary carcinomas has been observed in S100A4 transgenic mice $(9,11)$. S100A4 overexpression has been associated with a poor prognosis in a variety of human cancers, such as stomach, colon, breast, and gallbladder cancer (12-15).

E-Cadherin is the main cell-to-cell adhesion molecule that participates in homophilic, calcium-dependent interactions to form the epithelial adherence junction $(16,17)$. Inactivation of E-cadherin contributes to the reduction of cell-to-cell adhesiveness, followed by a loss of cellular polarity, the destruction of histological structures and the detachment of cells from the primary lesion (18). Loss or the reduced expression of E-cadherin correlates with distant metastasis in various advanced cancers, including pancreatic cancers (19). Thus, E-cadherin is assumed to act as a main invasion- 


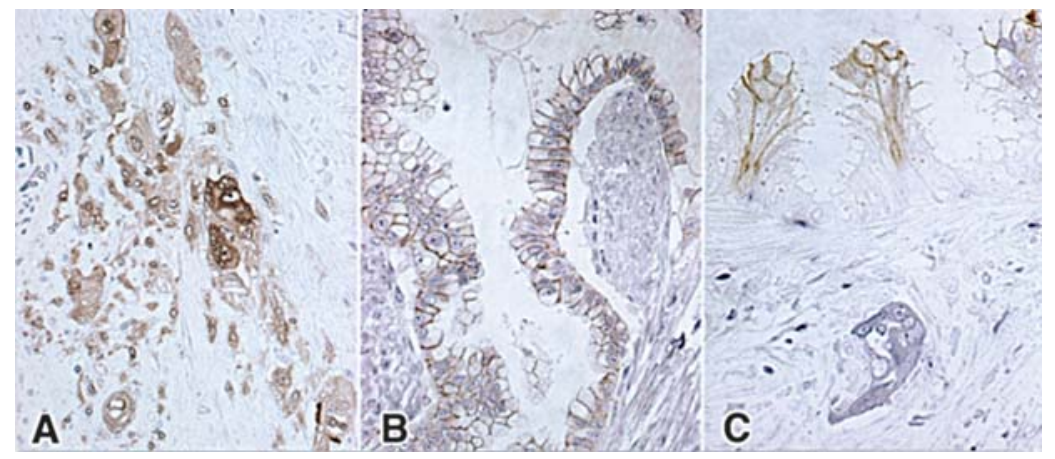

Figure 1. Immunohistochemical staining of S100A4 and E-cadherin in pancreatic cancer. (A) S100A4 is positive in the nuclei and cytoplasm of invasive poorly differentiated cancer cells. (B) Preserved expression of E-cadherin is observed in well differentiated adenocarcinoma nests. (C) Simultaneous immunohistochemical staining of S100A4 and E-cadherin demonstrates that the expression of membranous E-cadherin is preserved in the well differentiated cancerous nests (brown), while S100A4 is expressed in the poorly differentiated nests (blue).

Table I. Inverse correlation of S100A4 and E-cadherin expression in pancreatic cancer.

\begin{tabular}{llll}
\hline & \multicolumn{2}{l}{ E-Cadherin expression } & P-value \\
\cline { 2 - 3 } & $(-)(\%)$ & $(+)(\%)$ & \\
\hline $\begin{array}{l}\text { S100A4 expression } \\
(-)\end{array}$ & $10(31)$ & $22(69)$ & \\
$(+)$ & $31(77)$ & $9(23)$ & $<0.0001$ \\
\hline
\end{tabular}

Significance estimated with $\chi^{2}$ test.

suppressor molecule $(20,21)$. Recent studies reported the close correlations between S100A4 and E-cadherin expressions in the stomach, gallbladder, and lung cancer $(12,23,24)$.

In this study, we investigated the expression of S100A4 and E-cadherin in human pancreatic cancer and evaluated the significance for metastasis and prognosis.

\section{Materials and methods}

Specimens. Seventy-two specimens of primary pancreatic ductal adenocarcinoma were obtained by surgical resection from 1991 to 2000 with the patients' informed consent at the Department of Surgery, Tokai University School of Medicine. The patients consisted of 58 men and 14 women with a mean age of 63.2 years with a range of $48-84$ years. The pathological stages were classified according to the UICC tumor-node-metastasis (TNM) staging system (24), and the histological typing and differential grading of the pancreatic tumors were assigned according to the WHO criteria (25).

Immunohistochemistry. The formalin-fixed and paraffinembedded tissue samples were processed for immunohistochemistry. For S100A4 antigen retrieval, the deparaffinized sections were microwaved in $0.01 \mathrm{M}$ citrate buffer $(\mathrm{pH}$ 6.0) for $20 \mathrm{~min}$, and for E-cadherin, the sections were autoclaved in $1 \mathrm{mM}$ EDTA ( $\mathrm{pH} 8.0$ ) for $10 \mathrm{~min}$. After the blocking of endogenous peroxidase activity with $0.3 \% \mathrm{H}_{2} \mathrm{O}_{2}$ in methanol, these sections were incubated with rabbit polyclonal antiS100A4 antibody (1:100 dilution in PBS) or mouse monoclonal anti-E-cadherin antibody (1:100 dilution in PBS) at $4^{\circ} \mathrm{C}$ overnight. The immune complex was amplified with the biotinylated secondary antibodies, streptavidin-biotin complex, and streptavidin peroxidase (CSA, Catalyzed Signal Amplification system, Dako Co. Ltd., CA, USA). The amplified immune products were visualized using a 3,3'diaminobenzidine tetrahydrochloride (DAB) reaction.

Statistical analysis. The correlation between S100A4/Ecadherin expression and clinicopathological parameters was statistically evaluated using the $\chi^{2}$ test. Survival curves were plotted according to the method of Kaplan-Meier and a statistical comparison among groups was made by the use of the log-rank test. Multivariate analyses of survival was conducted using the Cox proportional hazard model and the log normal model. All statistical analysis were performed according to the SPSS version 10.0.7 (SPSS Inc., Chicago, IL, USA).

\section{Results}

S100A4 and E-cadherin expression status and clinicopathological parameters. To evaluate the relationships between the expression of S100A4 and E-cadherin in pancreatic cancer, 72 specimens of primary pancreatic cancer were analyzed by immunohistochemistry. S100A4 immunoreactive products were demonstrated in the cytoplasm and nuclei (Fig. 1A). S100A4 expression was not remarkable in normal pancreatic ductal epithelia and acini. E-cadherin expression was observed exclusively in the plasma membrane of normal pancreatic ducts and acini (Fig. 1B). Of the 72 pancreatic cancers, $40(56 \%)$ were positive and 32 $(44 \%)$ were negative for S100A4 expression. Thirty-one of the $40(77 \%)$ S100A4-positive cases were negative for Ecadherin expression. Twenty-two of the 32 (69\%) S100A4negative cases were positive for E-cadherin expression. The inverse correlation between the expression of S100A4 and Ecadherin was statistically significant $(\mathrm{p}<0.0001)$ (Table I). The inverse expression profiles of these two molecules were 
Table II. Correlation between the S100A4 expression and clinicopathological parameters in human pancreatic cancer.

\begin{tabular}{|c|c|c|}
\hline & & S100A4 expression \\
\hline $\begin{array}{l}\text { Clinico- } \\
\text { pathological } \\
\text { parameters }\end{array}$ & $\begin{array}{l}\text { No. of } \\
\text { patients }\end{array}$ & $\begin{array}{ll}\text { Negative } & \text { Positive } \\
\mathrm{n}=32(\%) & \mathrm{n}=40(\%)\end{array}$ \\
\hline
\end{tabular}

Age

$\begin{array}{lllll}<63 & 35 & 13(37) & 22(63) & \\ \geq 63 & 37 & 19(51) & 18(49) & 0.582\end{array}$

Gender

$\begin{array}{lrrrr}\text { Male } & 58 & 26(45) & 32(55) & \\ \text { Female } & 14 & 6(43) & 8(57) & 0.315\end{array}$

Histological grade

$\begin{array}{lrrrr}\text { G1 } & 18 & 12(67) & 6(33) & \\ \text { G2 } & 46 & 15(33) & 31(67) & \\ \text { G3 } & 8 & 5(62) & 3(38) & 0.141\end{array}$

T categories

$\mathrm{T} 1, \mathrm{~T} 2$

$\mathrm{T} 3$

T4

$\begin{array}{ccc}3 & 3(100) & 0(0) \\ 44 & 22(50) & 22(50) \\ 25 & 7(28) & 18(72)\end{array}$

$18(72)$

$0.024^{\mathrm{a}}$

$\mathrm{N}$ categories

NO

$127(58)$

$5(42)$

N1

$60 \quad 25(42)$

$35(58)$

0.44

$\mathrm{M}$ categories

$\begin{array}{lllll}\text { M0 } & 44 & 20(45) & 24(55) & \\ \text { M1 } & 28 & 12(43) & 16(57) & 0.829\end{array}$

TNM stage

\begin{tabular}{lrrrr} 
I, II & 4 & $3(75)$ & $1(25)$ & \\
III & 4 & $2(50)$ & $2(50)$ & \\
IVa & 36 & $14(37)$ & $22(63)$ & \\
IVb & 28 & $13(46)$ & $15(54)$ & 0.45 \\
\hline
\end{tabular}

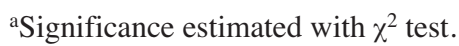

morphologically confirmed by double or simultaneous immunostaining procedures (Fig. 1C).

The relationships between $\mathrm{S} 100 \mathrm{~A} 4$ or E-cadherin expression and clinicopathological parameters are summarized in Tables II and III. No S100A4-positive tumors were observed in the T1 and T2 stages; in contrast, the high incidence of tumors in the T4 stage (72\%) showed a strong positive S100A4 expression. The correlation between S100A4positive expression and $\mathrm{T}$ factors was statistically significant $(p=0.024)$. The E-cadherin expression status showed no significant relationship with the clinicopathological parameters. According to the expression status of S100A4 and E-cadherin, pancreatic cancers were subdivided as
Table III. Correlation between E-cadherin expression and clinicopathological parameters in human pancreatic cancer.

E-Cadherin expression

Clinico-

pathological

No. of Negative Positive P-value parameters

Age

$<63$

$\geq 63$

$35 \quad 21(60) \quad 14(40)$

0.505

Gender

$\begin{array}{lrrrr}\text { Male } & 58 & 36(62) & 22(38) & \\ \text { Female } & 14 & 5(36) & 9(64) & 0.288\end{array}$

Histological grade

$\begin{array}{lrrrr}\text { G1 } & 18 & 7(39) & 11(61) & \\ \text { G2 } & 46 & 28(61) & 18(39) & \\ \text { G3 } & 8 & 6(75) & 2(25) & 0.130\end{array}$

$\mathrm{T}$ categories

$\begin{array}{lrrrr}\mathrm{T} 1, \mathrm{~T} 2 & 3 & 1(33) & 2(67) & \\ \mathrm{T} 3 & 44 & 24(55) & 20(45) & \\ \mathrm{T} 4 & 25 & 16(64) & 9(36) & 0.324\end{array}$

$\mathrm{N}$ categories

$\begin{array}{lrrrr}\text { N0 } & 12 & 8(20) & 4(13) & \\ \text { N1 } & 60 & 33(80) & 27(87) & 0.594\end{array}$

M categories

$\begin{array}{lllll}\text { M0 } & 44 & 24(55) & 20(45) & \\ \text { M1 } & 28 & 17(61) & 11(39) & 0.607\end{array}$

TNM stage

\begin{tabular}{lrrrr} 
I, II & 4 & $2(50)$ & $2(50)$ & \\
III & 4 & $2(50)$ & $2(50)$ & \\
IVa & 36 & $20(56)$ & $16(44)$ & \\
IVb & 28 & $17(61)$ & $11(39)$ & 0.886 \\
\hline
\end{tabular}

Significance estimated with $\chi^{2}$ test.

follows: i) S100A4-negative/E-cadherin-negative, ii) S100A4- negative/E-cadherin-positive, iii) S100A4positive/E-cadherin-negative and iv) S100A4-positive/Ecadherin-positive, as listed in Table IV. Ten $(56 \%)$ of 18 well-differentiated adenocarcinomas were subdivided in the S100A4-negative/E-cadherin-positive group.

S100A4 and E-cadherin expression status and survival. The 3-year-survival rates of patients with S100A4-negative and S100A4-positive cancers were $31.3 \%$ and $7.5 \%$, respectively. The median survival time (816 days) of patients with S100A4negative tumors was more than 2-fold longer than that (407 days) of patients with S100A4-positive cancers (Table V). Patients with S100A4-negative cancers depicted a significantly better survival curve than those with S100A4- 
Table IV. Correlation between S100A4/E-cadherin expression and clinicopathological parameters in human pancreatic cancer.

Clinicopathological parameters
S100A4 and E-cadherin (ECD) expression

S100A4 (-)/ECD (-) S100A4 (-)/ECD (+) S100A4 (+)/ECD (-) S100A4 (+)/ECD (+)

$\mathrm{n}=22(\%) \quad \mathrm{n}=10(\%) \quad \mathrm{n}=9(\%) \quad \mathrm{n}=31(\%) \quad$ P-value

Age

$<63$

$\geq 63$

9 (26)

$13(35)$

4 (11)

6 (16)

5 (49)

4 (11)

$17(14)$

$14(38)$

0.799

Gender

Male $17(29)$

Female

5 (36)

9 (16)

1 (6)

5 (8)

4 (29)

$2(10)$

4 (9)

4 (45)

1 (28)

7 (15)

1 (11)

1 (33)

7 (16)

2 (8)

0 (0)

5 (11)

4 (17)

3 (25)

7 (12)

0 (0)

9 (15)

26 (43)

0.363

M categories

M0

13 (30)

9 (32)

6 (14)

4 (14)

6 (14)

3 (11)

19 (42)

12 (43)

0.983

TNM stage

\begin{tabular}{|c|c|c|c|c|c|}
\hline I, II & $2(50)$ & $1(25)$ & $0(0)$ & $1(25)$ & \\
\hline III & $2(50)$ & $1(25)$ & $0(0)$ & $1(25)$ & \\
\hline IVa & $10(28)$ & $4(11)$ & $6(17)$ & $16(44)$ & \\
\hline $\mathrm{IVb}$ & 8 (29) & $4(14)$ & $3(11)$ & $13(46)$ & 0.863 \\
\hline
\end{tabular}

a Significance estimated with $\chi^{2}$ test. S100, S100A4; ECD, E-cadherin.

Table V. S100A4 and/or E-cadherin expression and patient survival.

\begin{tabular}{|c|c|c|c|c|c|}
\hline & $\begin{array}{l}\text { No. of } \\
\text { patients }\end{array}$ & $\begin{array}{c}\text { Median } \\
\text { survival day }\end{array}$ & $\begin{array}{c}\text { 1-Year } \\
\text { survival \% }\end{array}$ & $\begin{array}{c}2 \text {-Year } \\
\text { survival \% }\end{array}$ & $\begin{array}{c}\text { 3-Year } \\
\text { survival \% }\end{array}$ \\
\hline \multicolumn{6}{|l|}{ S100A4 expression } \\
\hline$(-)$ & 32 & 359 & 50 & 37.5 & 31.3 \\
\hline$(+)$ & 40 & 199 & 30 & 15 & 7.5 \\
\hline \multicolumn{6}{|l|}{ ECD expression } \\
\hline$(-)$ & 41 & 215 & 29.3 & 17.1 & 9.8 \\
\hline$(+)$ & 31 & 376 & 51.6 & 35.5 & 29 \\
\hline \multicolumn{6}{|l|}{ S100A4 and ECD expression } \\
\hline S100A4 (+)/ECD (-) & 31 & 181 & 29 & 16.1 & 9.7 \\
\hline S100A4 (-)/ECD (+) & 22 & 570 & 59.1 & 45.5 & 40.9 \\
\hline
\end{tabular}

ECD, E-cadherin. 


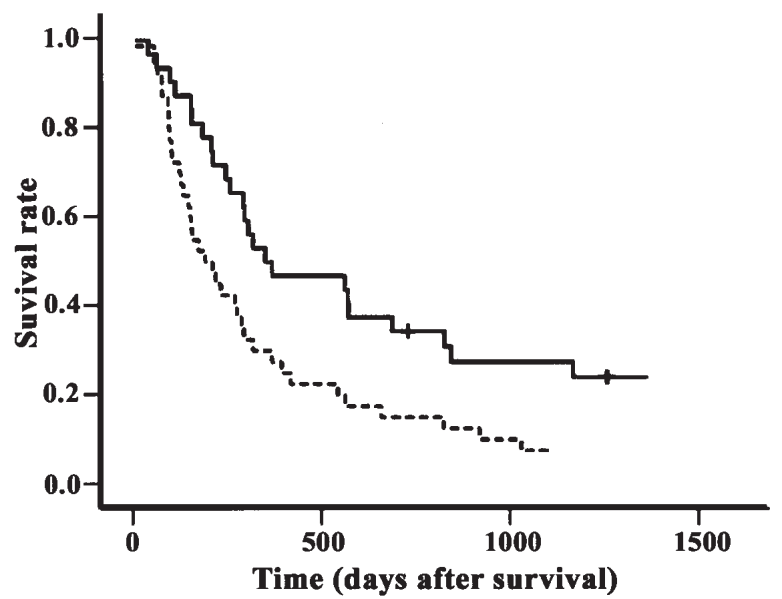

Figure 2. Survival curves of pancreatic cancer patients grouped according to S100A4 expression. Patients with S100A4-positive tumors (- - , n=40) had a significantly poor prognosis compared those with S100A4-negative tumors $(-, \mathrm{n}=32 ; \mathrm{p}=0.0136, \log$-rank test).

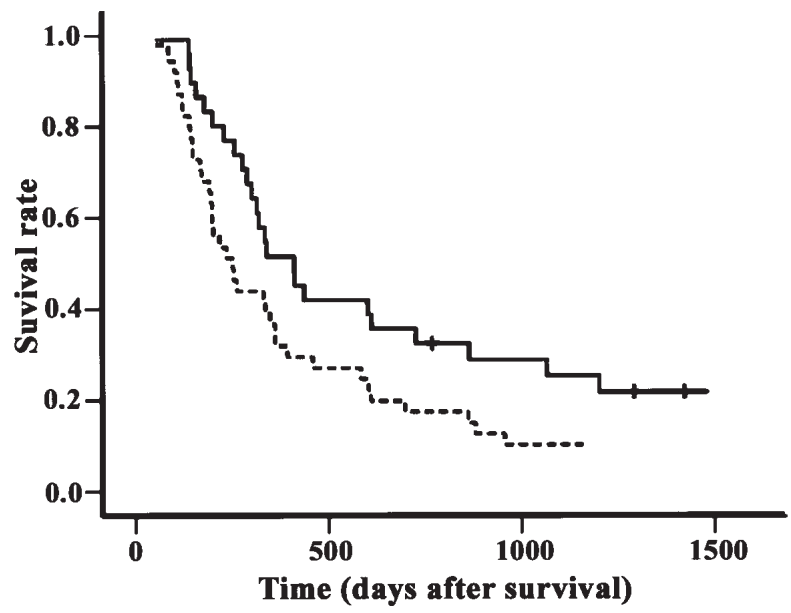

Figure 3. Survival curves of pancreatic cancer patients grouped according to E-cadherin expression. Patients with E-cadherin-negative tumors (- - - , $\mathrm{n}=41$ ) had a significantly poor prognosis compared to that of patients with E-cadherin-positive tumors $(-,-n=31 ; \mathrm{p}=0.0344$, log-rank test $)$.

positive cancers ( $\mathrm{p}=0.0136$; log-rank test) (Fig. 2). The survival of patients with E-cadherin-positive cancers was significantly better than that of patients with E-cadherin-negative tumors ( $\mathrm{p}=0.0344$; log-rank test) (Fig. 3). Fig. 4 shows the survival curves of four groups of patients subdivided according to the expression of S100A4 and E-cadherin. The patients with S100A4 negative/E-cadherin positive cancers presented the highest 3-year survival rate $(40.9 \%)$, as compared to the other three groups. The patients with S100A4-negative/Ecadherin positive cancers showed a significantly better prognosis than those of the other three groups $(\mathrm{p}<0.01 ; \log$ rank test). There was no significant difference in the survival rate between these three groups. A multivariate Cox proportional hazard regression analysis showed that the histological grade $(\mathrm{p}=0.004)$, nodal status $(\mathrm{p}<0.0001)$ and S100A4-positive status $(\mathrm{p}=0.048)$ were highly significant independent prognostic predictors $(\mathrm{p}<0.05)$ (Table VI). Patients with S100A4 positive/E-cadherin negative cancers

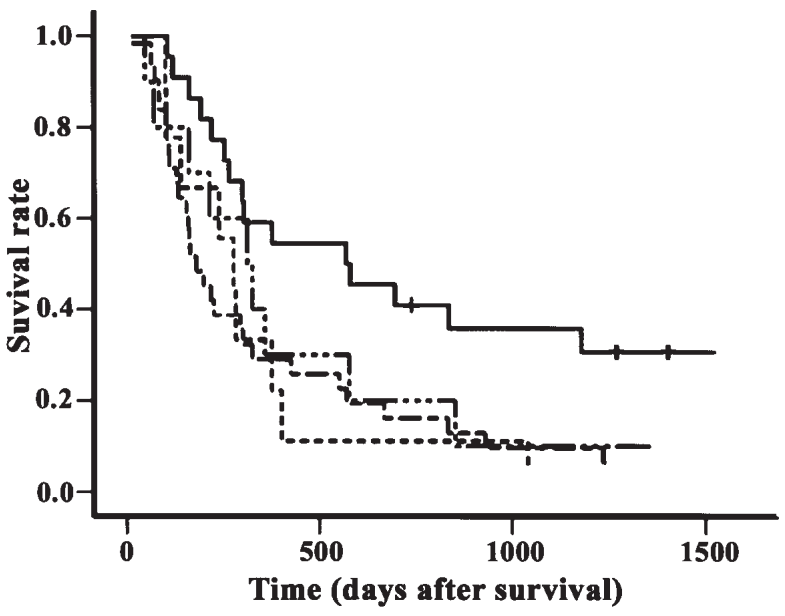

Figure 4. Survival curves of four groups subdivided according to the expression status of S100A4 and E-cadherin. Patients with S100A4 (-)/ECD $(+)$ tumors $(-, \mathrm{n}=22)$ had a significantly better prognosis than did those with the tumors of the other three groups, S100A4 (-)/ECD (-) (- - - , $\mathrm{n}=10)$, S100A4 (+)/ECD (-) (- - n=31), S100A4 (+)/ECD (+) (- - , n=9; $\mathrm{p}<0.05, \log$-rank test). There was no significant difference in the survival of patients of the other three groups.

showed about a 2-fold higher relative risk for death than those with S100A4 negative/E-cadherin positive cancers $(\mathrm{p}=0.011)$.

Recurrence was observed in $60(83.3 \%)$ of 72 pancreatic cancer patients (Table VII). Liver metastasis was significantly frequent in patients with E-cadherin-negative cancers $(\mathrm{p}=0.027)$. The S100A4-positive/E-cadherin negative cancers showed a significantly higher incidence of liver metastasis $(\mathrm{p}=0.04)$.

\section{Discussion}

In this study, the S100A4 and E-cadherin expression status was evaluated in relation to the clinicopathological significance in pancreatic cancer. S100A4 expression was observed in $56 \%$ of the 72 pancreatic cancers. The overexpression of S100A4 was significantly correlated with poor prognosis and the clinicopathological parameter, $\mathrm{T}$ factor. Furthermore, S100A4-positive cancers were associated with postoperative outcomes and liver metastasis. Our results suggest that the overexpression of S100A4 induces poor prognosis in patients through facilitating an invasive and metastatic ability in pancreatic cancer. Significant association of S100A4 to lymph node metastasis have been reported in several types of cancer, such as stomach, breast, colon and mouth cancer (12$14,26)$. Our results did not show a close relationship between S100A4 and nodal metastases in pancreatic cancer. The critical roles of S100A4 expression may be tumor-type dependent. S100A4 molecules may modulate the cell cycle, cell motility, cell adhesion and invasive properties (27-29). Rat mammary epithelial cell lines transfected with S100A4 cDNA increase the metastatic potential, whereas antisense S100A4 RNA or anti-S100A4 ribozyme suppresses the metastatic ability (30). The results suggest that S100A4 plays important roles in initiating the multi-step process that begins with the detachment of cancer cells from the primary lesion and ends with their attachment to a different organ. 
Table VI. Multivariate analysis of clinicopathological features as a prognostic factor.

\begin{tabular}{|c|c|c|c|}
\hline Variables & Relative risk & Confidence interval & P-value \\
\hline \multicolumn{4}{|l|}{ Histological grade } \\
\hline G3 vs G1 & 4.091 & $1.580-10.590$ & $0.004^{\mathrm{a}}$ \\
\hline \multicolumn{4}{|l|}{$\mathrm{N}$ grade } \\
\hline N1 vs N0 & 4.971 & $2.132-11.595$ & $<0.0001$ \\
\hline \multicolumn{4}{|l|}{ TNM stage } \\
\hline III, IV vs I,II & 2.926 & $0.773-11.073$ & 0.114 \\
\hline \multicolumn{4}{|l|}{ Expression of S100A4 } \\
\hline$(+)$ vs $(-)$ & 1.814 & $1.006-3.270$ & $0.048^{\mathrm{a}}$ \\
\hline \multicolumn{4}{|l|}{ Expression of ECD } \\
\hline$(-)$ vs $(+)$ & 1.264 & $0.733-2.180$ & 0.399 \\
\hline \multicolumn{4}{|c|}{ Expression of S100A4 and ECD } \\
\hline \multicolumn{4}{|c|}{ S100A4 (+)/ECD (-) } \\
\hline vs S100A4 (-)/ECD (+) & 2.276 & $1.206-4.273$ & $0.011^{\mathrm{a}}$ \\
\hline
\end{tabular}

aSignificance estimated with $\chi^{2}$ test. ECD, E-cadherin.

Table VII. S100A4 and/or E-cadherin expression and postoperative outcomes.

\begin{tabular}{|c|c|c|c|c|c|c|c|c|c|}
\hline & \multicolumn{2}{|c|}{ S100A4 } & \multirow[b]{2}{*}{ P-value } & \multicolumn{2}{|c|}{ ECD } & \multirow[b]{2}{*}{ P-value } & \multicolumn{2}{|c|}{ S100A4/ECD } & \multirow[b]{2}{*}{ P-value } \\
\hline & $\begin{array}{c}(-) \\
n=25\end{array}$ & $\begin{array}{c}(+) \\
n=35\end{array}$ & & $\begin{array}{c}(-) \\
n=35\end{array}$ & $\begin{array}{c}(+) \\
n=25\end{array}$ & & $\begin{array}{c}\mathrm{S} 100(-) / \\
\operatorname{ECD}(+) \\
n=16\end{array}$ & $\begin{array}{c}\mathrm{S} 100(+) / \\
\operatorname{ECD}(-) \\
\mathrm{n}=27\end{array}$ & \\
\hline \multicolumn{10}{|c|}{ Liver metastasis } \\
\hline$(-)$ & 14 & 15 & & 12 & 17 & & 11 & 10 & \\
\hline$(+)$ & 11 & 20 & 0.06 & 23 & 8 & $0.027^{\mathrm{a}}$ & 5 & 17 & $0.04^{\mathrm{a}}$ \\
\hline \multicolumn{10}{|c|}{ Peritoneal dissemination } \\
\hline$(-)$ & 16 & 26 & & 27 & 15 & & 8 & 20 & \\
\hline$(+)$ & 9 & 9 & 0.896 & 8 & 10 & 0.593 & 8 & 7 & 0.82 \\
\hline \multicolumn{10}{|c|}{ Lymph node recurrence } \\
\hline$(-)$ & 22 & 25 & & 26 & 21 & & 15 & 20 & \\
\hline$(+)$ & 3 & 10 & 0.073 & 9 & 4 & 0.246 & 1 & 7 & 0.11 \\
\hline \multicolumn{10}{|c|}{ Local recurrence } \\
\hline$(-)$ & 23 & 28 & & 30 & 21 & & 14 & 22 & \\
\hline$(+)$ & 2 & 7 & 0.085 & 5 & 4 & 0.449 & 2 & 5 & 0.3 \\
\hline
\end{tabular}

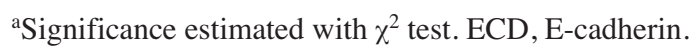

The relationship of S100A4 expression with the downregulation of E-cadherin was initially reported in mouse mammary tumor cells (31). Subsequent studies further supported the evidence that there was an inverse correlation between the expression of S100A4 and E-cadherin in several human cancers such as stomach, lung, gallbladder and malignant melanoma $(12,15,23,32)$. Our results clearly revealed an inverse correlation of S100A4 and E-cadherin expression in pancreatic cancer specimens. E-Cadherin is a prerequisite for cell-cell adhesion and maintaining the epithelial structure. The decrease or loss of E-cadherin contributed to the reduction of cell-to-cell adhesiveness, followed by the loss of cell polarity and the destruction of structures. It may induce cells to dissociate from their primary tumors and invade the surrounding tissue or metastasize to distant organs (18). In our study, the E- 
cadherin-negative tissue status also had a significant association with poor prognosis and a significant value in predicting liver recurrence. E-Cadherin itself is an independent prognostic factor, as is $\mathrm{S} 100 \mathrm{~A} 4$, in pancreatic cancer (33).

Our results demonstrate that the expression status of S100A4-negative/E-cadherin-positive cancers significantly predicts a longer survival of patients than the other three groups. Cox's hazard regression model analysis showed that patients with S100A4-positive/E-cadherin-negative tumors had a more than 2-fold relative risk of death than those with S100A4-negative/E-cadherin-positive tumors $(\mathrm{p}<0.05)$.

In conclusion, the expression status of S100A4 and Ecadherin might be useful for the evaluation of prognosis and postoperative recurrence in patients with pancreatic cancer. Further investigation of the mutual biological functions of S100A4 and E-cadherin may allow us to develop appropriate therapeutic strategies for pancreatic cancer.

\section{Acknowledgements}

We thank Mr. Yuichi Tada, Dr Johbu Itoh and Dr Yoshiko Itoh for their technical assistance.

\section{References}

1. Murr MM, Sarr MG, Oishi AJ and Van Heerden JA: Pancreatic cancer. CA. Cancer J Clin 44: 304-318, 1994.

2. Iwamura $\mathrm{T}$, Katsuki $\mathrm{T}$ and Ide $\mathrm{K}$ : Establishment and characterization of a human pancreatic cacer cell line (SUIT-2) producing carcinoembryonic antigen and carbohydrate antigen 19-9. Jpn J Cancer Res 78: 54-62, 1987.

3. Shafer BW and Heizmann CW: The S100 family of EF-hand calcium binding proteins: functions and pathology. Trends Biochem Sci 21: 134-140, 1996.

4. Watanabe $Y$, Kobayashi R, Ishikawa $T$ and Hidaka H: Isolation and characterization of a calcium-binding protein derived from synthesized vasorelaxant W-66 affinity chromatography. Arch Biochem Biophys 292: 563-569, 1992.

5. Ebralidze A, Tulchinsky E, Grigorian M, Afanasyeva A, Senin V, Revazova E and Lukanidin E: Isolation and characterization of a gene specifically expressed in different metastatic cells and whose deduced gene product has a high degree of homology to a Ca ${ }^{2+}$-binding protein family. Genes Dev 3: 1086-1093, 1989.

6. Mazzucchelli L: Protein S100A4: too long overlooked by pathologists? Am J Pathol 160: 7-13, 2002.

7. Davies BR, Davies MP, Gibbs FE, Barraclough R and Rudland PS: Induction of the metastatic phenotype by transfection of a benign rat mammary epithelial cell line with the gene for $\mathrm{p} 9 \mathrm{Ka}$, a rat calcium-binding protein, but not with the oncogene EJ-ras-1. Oncogene 8: 999-1008, 1993.

8. Grigorian M, Ambertsumian N, Lykkesfeldt AE, Bastholm L, Elling F, Georgiev G and Lukanidin E: Effect of mts1 (S100A4) expression on the progression of human breast cancer cells. Int J Cancer 67: 831-841, 1996.

9. Davies MPA, Rudland PS, Robertson L, Parry E, Jolicocur P and Barraclough R: Expression of calcium binding protein S100A4 in MMTV-neu transgenic mice induces metastasis of mammary tumours. Oncogene 13: 1631-1637, 1996.

10. Lloyd BH, Platt-Higgins A, Rudland PS and Barraclough R: Human S100A4 (p9Ka) induces the metastatic phenotype upon benign tumour cells. Oncogene 17: 465-473, 1998.

11. Barraclough R: Calcium binding protein S100A4 in health and disease. Biochim Biophys Acta 1448: 190-199, 1998.

12. Yonemura Y, Endou Y, Kimura K, Fushida S, Bandou E, Taniguchi K, Kinoshita K, Ninomiya I, Sugiyama K, Heizmann CW, Schafer BW and Sasaki T: Inverse expression of S100A4 and E-cadherin is associated with metastatic potential in gastric cancer. Clin Cancer Res 6: 4234-4242, 2000 .
13. Gongoll S, Peters G, Mengel M, Piso P, Klempnauer J, Kreipe H and Wasielewski RV: Prognostic significance of calciumbinding protein S100A4 in colorectal cancer. Gastroenterology 123: 1478-1484, 2002.

14. Rudland PS, Platt-Higgins A, Renshaw C, West CR, Winstanley JH, Robertson L and Barraclough R: Prognostic significance of the metastasis-inducing protein S100A4 (p9Ka) in human breast cancer. Cancer Res 60: 1595-1603, 2000.

15. Nakamura T, Ajiki T, Murao S, Kamigaki T, Maeda S, Ku Y and Kuroda Y: Prognostic significance of S100A4 expression in gallbladder cancer. Int J Oncol 20: 937-941, 2002.

16. Takeichi M: Cadherin cell adhesion receptors as a morphogenetic regulator. Science 251: 1451-1455, 1991.

17. Wheelock MJ and Jensen PJ: Regulation of keratinocyte intercellular junction organization and epidermal morphogenesis by E-cadherin. J Cell Biol 117: 415-425, 1992.

18. Hirohashi S: Inactivation of the E-cadherin-mediated cell adhesion system in human cancers. Am J Pathol 153: 333-339, 1998.

19. Pignatelli M, Ansari TW, Gunter P, Liu D, Hirano S, Takeichi M, Kloppel $\mathrm{G}$ and Lemoine NR: Loss of membranous E-cadherin expression in pancreatic cancer: correlation with lymph node metastasis, high grade, and advanced stage. J Pathol 174: 243-248, 1994.

20. Frixen UH, Behrens J, Sachs M, Eberle G, Voss B, Warda A, Löchner D and Birchmeier W: E-cadherin-mediated cell-cell adhesion prevents invasiveness of human carcinoma cells. J Cell Biol 113: 173-185, 1991.

21. Behrens J, Mareel MM, Van Roy FM and Birchmeier W: Dissecting tumor cell invasion: epithelial cells acquire invasion properties after the loss of uvomorulin-mediated cell-cell adhesion. J Cell Biol 108: 2435-2447, 1989.

22. Kohya N, Kitajima Y, Jiao W and Miyazaki K: Effects of Ecadherin transfection on gene expression of a gall bladder carcinoma cell line: Repression of MTS1/S100A4 gene expression. Int J Cancer 104: 44-53, 2003.

23. Kimura K, Endo Y, Yonemura Y, Heizmann CW, Schäfer BW, Watanabe $\mathrm{Y}$ and Sasaki T: Clinical significance of S100A4 and E-cadherin-related adhesion molecules in non-small cell lung cancer. Int J Oncol 16: 1125-1131, 2000.

24. TNM classification of Malignant Tumors. Sobin LH and Wittekind CH (eds). Wiley-Liss, New York, pp87-90, 1997.

25. Klöppel G and Maillet B: Histological typing of pancreatic and periampullary carcinoma. Eur J Surg Oncol 17: 139-152, 1991.

26. Moriyama-Kita M, Endo Y, Yoneyama Y, Heizmann CW, Schäfer BW, Sasaki T and Yamamoto E: Correlation of S100A4 expression with invasion and metastasis in oral squamous cell carcinoma. Eur J Cancer B Oral Oncol 40: 496-500, 2004.

27. Takenaga A, Nakamura $Y$, Endo $H$ and Sakiyama S: Involvement of S100 related calcium binding protein pEL98 (or $m t s 1)$ in cell motility and tumor cell invasion. Jpn J Cancer Res 85: 831-839, 1994.

28. Ford HL, Salim MN, Chakravarty R, Aluiddin V and Zain SB: Expression of $m t s l$, a metastasis-associated gene, increases motility but not invasion of a nonmetastatic mouse mammary adenocarcinoma cell line. Oncogene 11: 2067-2075, 1995.

29. Grigorian MS, Tulchinsky EM, Zain S, Ebralidze AK, Kramerov DA, Kriajevska MV, Georgiev GP and Lukanidin EM: The $m t s 1$ gene and control of tumor metastasis. Gene 135: 229-238, 1993.

30. Mælandsmo GM, Hoving E, Skrede M, Engebraaten O, Florenes VA, Myklebost O, Grigorian M, Lukanidin E, Scanlon KJ and Fodstad O: Reversal of the in vivo metastatic phenotype of human tumor cells by an anti-CAPL ( $m t s 1$ ) ribozyme. Cancer Res 56: 5490-5498, 1996.

31. Keirseblick AB, Bonne S, Bruyneel E, Vermassen P, Lukanidin E, Mareel M and van Roy F: E-cadherin and metastasin (mts-1/ S100A4) expression levels are inversely regulated in two tumor cell families. Cancer Res 58: 4587-4591, 1998.

32. Anderson K, Nesland JM, Holm R, Florenes VA, Fodstad O and Mælandsmo GM: Expression of S100A4 combined with reduced E-cadherin expression predicts patient outcome in malignant melanoma. Mod Pathol 17: 990-997, 2004.

33. Li YJ, Meng YX and Ji XR: Relationship between expression of E-cadherin and alpha-catenin and biological behaviors of human pancreatic cancer. HBPD Int 2: 471-477, 2003. 